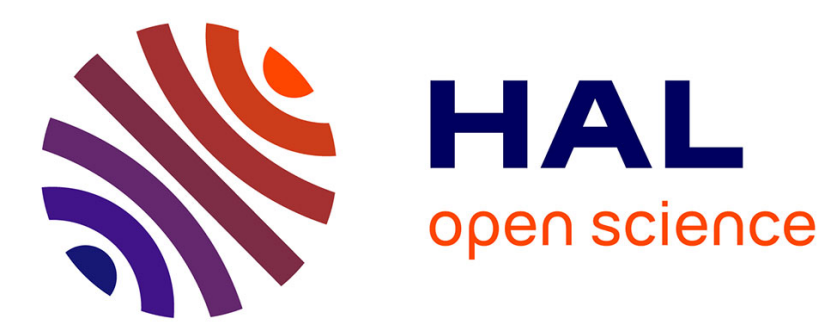

\title{
MODELLING OF LASER INDUCED METALLURGICAL TRANSFORMATIONS IN TITANIUM ALLOYS AND CARBON STEELS
}

A. Gordienko, S. Bushik, Ju. Mookhin

\section{- To cite this version:}

A. Gordienko, S. Bushik, Ju. Mookhin. MODELLING OF LASER INDUCED METALLURGICAL TRANSFORMATIONS IN TITANIUM ALLOYS AND CARBON STEELS. Journal de Physique IV Proceedings, 1991, 01 (C7), pp.C7-135-C7-135. 10.1051/jp4:1991731 • jpa-00250934

\section{HAL Id: jpa-00250934 https://hal.science/jpa-00250934}

Submitted on 1 Jan 1991

HAL is a multi-disciplinary open access archive for the deposit and dissemination of scientific research documents, whether they are published or not. The documents may come from teaching and research institutions in France or abroad, or from public or private research centers.
L'archive ouverte pluridisciplinaire HAL, est destinée au dépôt et à la diffusion de documents scientifiques de niveau recherche, publiés ou non, émanant des établissements d'enseignement et de recherche français ou étrangers, des laboratoires publics ou privés. 


\section{MODELLING OF LASER INDUCED METALLURGICAL TRANSFORMATIONS IN TITANIUM ALLOYS AND CARBON STEELS}

A.I. GORDIENKO, S.V. BUSHIK and Ju.V. MOOKHIN

The Physical-Technical Institute of the BSSR Academy of Science, Zhodinskaja 4, Minsk 220730, BSSR, USSR

The laws of phage $\alpha+\beta \rightarrow \beta$-trangformation in Ti-6Al-4V alloy and $\alpha->\gamma$-transformation in eutectic carbon steel during heat treatment using laser irradiation have been established.

The coefflolent of vanadium diffusion in titanium alloy is known to be muoh less than the coeffloient of oarbon diffusion in steel in the same conditions. It leads to a different rate and degree of oompleting of phase transformations in titanium alloy and steel. The evaluation of these effects was performed by solving diflusion equations with the appropriate boundary conditions.

It is shown that at a definite heating rate a difusive phase transition mechanism turns into the difusionless one. The values of these "oritianl heating rates were estimated to be $10^{2} \mathrm{c} / \mathrm{s}$ for titanium alloy and $10^{4}-10^{5} \mathrm{C} / \mathrm{s}$ for steel. Comparing these values with average heating rates during laser irradiation it is possible to make a conolusion about the degree of diffusion or diffusionless mechantsm realization.

It is shown that during oontinuous $\mathrm{CO}_{2}$-laser heating even up to the melting point the $\alpha+\beta \rightarrow \beta$-traneformation in titanium alloy proceeds mainly by a non-diflusion mechanism, the phase composition after oooling being determined by the degree of completion of $\beta$-phase homogenization process. On the contrary $\alpha>\gamma$-transformation in steel during laser irradiation proceeds by a diffusion mechanism. On the basis of calculated data the suitable hardening regimes of laser heat treatment are also discussed. 